\title{
CONCEPT OF HYPERLIPIDAEMIA IN THE LIGHT OF UNANI SYSTEM OF MEDICINE
}

\author{
Salma Shaikh ${ }^{1}$, A.H. Farooqui ${ }^{2}$, Siraj Shaikh ${ }^{3}$, Khan Maherosh ${ }^{4}$ \\ Tausif S. Khan ${ }^{5}$ and Sumaiyya Salar ${ }^{6}$
}

\begin{abstract}
${ }^{1 *}$ PG Scholar, Department of Moalijat, ZVM Unani Medical College and Hospital, Pune,Maharashtra, India
${ }^{2}$ Assoc-Professor and HODofMoalijat in ZVM Unani Medical College and Hospital, Pune,Maharashtra, India ${ }^{3}$ Asstt Professor and HOD of Amraz-e-Jild-wa-Taziniyat

ZVM Unani Medical College and Hospital, Pune, Maharashtra, India

${ }^{4}$ PG Scholar, Department of Moalijat, ZVM Unani Medical College and Hospital, Pune, Maharashtra, India ${ }^{5}$ HOD \& Assistant Professor, Department of Mahiyatul Amraz ZVM Unani Medical College Pune, Maharashtra India. ${ }^{6}$ Dept of Ilmul Jarahat, Iqra Unani medical College Jalgaon, Maharashtra India.
\end{abstract}

\section{Review Paper}

\begin{abstract}
Hyperlipidemia is a term that encompasses various genetic and acquired disorders that describe elevated lipid levels within the body. Hyperlipidemia itself does not typically lead to critical symptoms itself; however, having this underlying pathology will often lead to serious illnesses that may ultimately lead to death. To lower morbidity and mortality rates associated with this disorder, it is critical to establish an early diagnosis and prevent the progression of the disease. Unani System of Medicine is familiar of management of hyperlipidemia by various methods. The present paper describes the concept of hyperlipidemia (Fart-e-Tadassum fid-dam) and management with reference to the Unani concept.
\end{abstract}

No. of Pages: 4

References: 27

Keywords: Hyperlipidemia, fart-e- tadassum fid dam, obesity.

\section{INTRODUCTION}

The Concept of hyperlipidemia (Farte-e- Tadassum-FidDam) is new and based on the biochemical changes in the blood i.e. distributed lipid metabolism and as a result there is increase concentration of lipids in blood. ${ }^{1,2}$ hyperlipidemia is a highly atherogenic lipid metabolic disorder characterized by abnormally elevated levels of circulating cholesterol or triglycerides, it is known as combined hyperlipidemia (CHL)
${ }^{3}$ It is also known as hyperlipoproteinemia or dyslipidemia. It results either from increase in synthesis or decrease in degradation of lipoproteins, which transport cholesterol \&

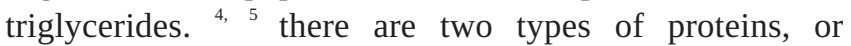
lipoproteins that transport cholesterol to the cells: Lowdensity lipoproteins (LDL), or bad cholesterol, and highdensity lipoproteins (HDL), or good cholesterol. LDL has damaging effects on health. HDL, however, counteracts the

*Corresponding author: shaikhsalma817@gmail.com 
effects of LDL. HDL is good for health as it carries excess cholesterol back to the liver for excretion. The liver then eliminates cholesterol through bile. LDL that remains in the bloodstream damages health, because it allows excess cholesterol to build up in the blood. Triglycerides are another type of fat in the blood. They are not a type of cholesterol but have a strong association with heart disease. ${ }^{6}$

In Unani system of medicine, renowned Unani scholar Abu Sahal Maseehi had given the concept of dosoomat-e-khoon (oily substance in blood) ${ }^{7}$ The Hippocrates, Razes,and Avicenna described the obesity (Saman-e-mufrit), which is due to the excessive phlegm (Khilt-e- Balgham) ${ }^{8,9}$

A person can develop hyperlipidemia if they have one or a combination of the following: ${ }^{10,12,15,16}$

- high LDL levels

- high HDL levels

- elevated levels of triglycerides

> The following table highlights the ideal cholesterol levels

\begin{tabular}{|l|l|}
\hline Overall cholesterol & $\begin{array}{l}\text { Under } 200 \text { milli grams per } \\
\text { deciliter }(\mathbf{m g} / \mathbf{d l})\end{array}$ \\
\hline HDL cholesterol & $\begin{array}{l}\text { Men: More than } 40 \mathrm{mg} / \mathrm{dl} \\
\text { Women: More than } 50 \mathrm{mg} / \mathrm{dl}\end{array}$ \\
\hline LDL cholesterol & $\begin{array}{l}\text { Otherwise healthy people: Less } \\
\text { than } 100 \mathrm{mg} / \mathrm{dl}\end{array}$ \\
$\begin{array}{l}\text { People with heart disease or } \\
\text { diabetes or poorly controlled } \\
\text { risk factors: Less than } 70 \\
\text { mg/dl }\end{array}$ \\
\hline Triglycerides & Less than $150 \mathrm{mg} / \mathrm{dl}$ \\
\hline
\end{tabular}

ETIOLOGY: ${ }^{13,17,18}$

$>$ Hyperlipidemia can be caused by some genetic abnormalities but it can also happen due to some other disorders that change the lipid metabolism of the body. One other main cause of hyperlipidemia is eating foods which contain high quantities of saturated fats, trans-fats and cholesterol. These fatty and oily foods can cause an increase in the levels of lipids inside the body resulting into hyperlipidemia.

$>$ Most of the causes of obesity (Saman-e-Mufrat) described by ancient Unani physicians are very similar to the causes of hyperlipidemia (Farte-eTadassum-Fid-Dam)

1. Hereditary (Virasat, Khilqi): The obesity which is present in a family (genetic origin) $\mathrm{s}$ called hereditary obesity or primary obesity.
2. Exercise (Riyazat) \& life style: lack of exercise and sedentary life style.

3. Diet (Ghiza): Use of excessive amount of carbohydrate, fat, and other dietary substances that produce excessive amount of Khilt-e- Balgham in body.

\section{PHYSIOLOGY OF LIPIDS: ${ }^{18,19,20,22}$}

Unani scholars were familiar about the presence of fat (shaham) in blood, so they have mentioned elaborately regarding obesity. "Fat (shaham and sameen) is a white and very soft entity which is most of the times found along or around fascia and nervous tissues. Temperament of fat is cold". Ibne Rushd says that "fat (shaham) is the metabolic waste product (fuzla) of mature blood (nuzuzyafta dam) from which different organs of body obtains their nutrition. Average quantity of fat (shaham) is a sign of health and low level indicates immaturity of blood (Adam pukhtagi of dam) or the person is undernourished and excess of fat is not good for health. Sheikh Ibn-e-Sina (980-1030AD) in "Al Qanoon fit- Tib" has described "Fat is formed from wateriness and greasiness of the blood and cold coagulates it. This is why heat dissolves it" Allama Kabeeruddin in his book "Ifaada-eKabeer Mufassal” has quoted Abu Sahel Maseehi about the production of fat in the body he says that: 'Factor responsible for the production of fat in the body is coldness and this is the reason why fat is not found or found negligible in and around hot entities.

\section{CLASSIFICATION OF FAT (SHAHAM): ${ }^{21}$}

According to Abu Sahel Maseehi (970-1010 AD) fat is of two types:

1. Sameen: It is soft, semisolid and has less property to solidify.

2. Shaham: It is hard and is found in the body adherent to kidneys.

"Both shaham and sameen are formed by that blood which has the property of 'Dasoomat' (meaning oily substance)

\section{Pathophysiology of Fart-e-Tadassum fid-Dam in Unani ${ }^{17}$ 18,23}

It is described in the context of obesity. People with the symptoms of Saman-e-Mufrat are more prone to diseases as their Hararat Ghareezia becomes very weak due to Baroodate Mizaj and constriction of vessels (Tangi Urooq). These two factors cause early death of obese persons. Due to the vaso constriction, Hararat Ghareezia becomes weak and slow and weakness of Hararat Ghareezia causes itself vaso constriction. These are dependent to each other in a positive feedback system and both these factors finally leads to decrease in the passage of Rooh to the organs and finally death occur. $[2,10]$ In normal physiology, vessels are dilated 
and their dilatation is essential for the supply of Ghiza (nutrition) and Rooh (oxygen supply) to Aaza. In obesity, excessiveaccumulation of Shaham (fat) in body and Balgham in blood causes "Imtilai Kaifiyat" (increase invasopressor) which causes loss of vasodilatation of vessels and finally decreases the Hararat Ghareezia. ${ }^{23}$

\section{Clinical Features: ${ }^{8,23}$}

$>$ First time Hippocrates describe the clinical features \& complications in these words "when a person becomes extreme obese, Imtilai-dam may lead to sudden death because of hemorrhage (due to rupture of vessels) or due to loss of Hararat. Obese persons are prone to other diseases as well as death because of Narrowing.

> In extreme obesity, dyspnea (tangiye tanaffus)as well as palpitation (Ikhtilaj-e-qalb) develops.

$>$ Duration of any disease in obese person is moreprolonged in comparison to healthy people.

\section{USOOL-E- ILAAJ (PRINCIPLES OF TREATMENT) ${ }^{21,}$} 23,24

> Following Principles are very important in the treatment of obesity as follows:

1. Weight reduction

2. Maintenance of healthy state (Baqa-e-Sehat)

3. Taqleel-e-Ghiza (Low diet)

4. Kasrat-e-Riyazat (Exercise)

5. Ishal (Diarrhoea)

6. Idrar-e- baul (Diuretic)

7. Tareeq (Diaphoresis)

8. Dalak-e-Khashin (Rough massage)

9. Massage with Mohallil Roghaniyat

$>$ Razi has classified all these treatment broadly into three categories as:

1. Taqleel Ghiza (decrease in food intake)

2. Riyazat Kaseera (too much exercise)

3. Ishaal wa Idraar (Diarrhoea and diuretic), Fasad(venesection) and Istifrag (evacuation)

\section{ILLAJ BIL DAWA(DRUG THERAPY) ${ }^{16,25,26}$}

\section{$>$ Mufrad Advia (Single drugs):}

There are a large number of single drugs (Adviamufrada) which have been used by various Unani physicians for the treatment of obesity (Samanemufrat) in the ancient unani literature e. g. "Ajwayin Khurasani (Hyoscyamus niger) , Ajwain Desi (Carumcopticum), Filfil siyah (Piper nigrum),Kalonji (Nigella sativa), Khardal (Brassica nigra),Lahsun (Allium sativum), Luk
Maghsool (Coccuslacca), Marzanjosh (Oliganum vulgare), Namak Lahori (Sodium chloride), Nana (Mentha arvensis), Sirka (Vinegar), Zeera kirmani (Carum carvi)

Ø Murakkab Advia ( Compound Formulations): Arq-e-Badiyaan, Arq-e- Zeera , Jawarish Kamooni, Jawarish Falafili, Safoof Mohazzil, safoof-e- darcheni.

\section{REFRENCES}

1. Braunwald fuci \& other, Harrison's Principle of Internal Medicine, $15^{\text {th }}$ edition MaGraw-Hill, 2001, Vol I, p-2249-2251.

2. D J Weatherall \& Other, Oxford Text Book of Medicine, $3^{\text {rd }}$ edition, oxford medical publication, Vol. IInd, 1996, p-1399,1404-1414.

3. Parveen kumar \& Micheal Clark, Clinical Medicine, $4^{\text {th }}$ edition, W B Saunders, 1998,p-686,991-995.

4. G.S. Sainani, API Text Book of Medicine, $6^{\text {th }}$ edition, The Association of physicians of India 2002, p191-665.

5. John A.A. Hunter \& others, Davidson's Principles and Practice of Medicine, 19th edition, Churchill Livingstone, 2002 p 30.

6. Farnier M., Picard S., Diabetes: statins, fibrates, Atherosclerosis rep 3:19-28,2001

7. Libby, Bonow munn, Zipes," Braunwald;s Heart Diseases” , $8^{\text {th }}$ Ed, Saunders Elsevier Publications, Philadelphia, USA:1007-1012,1019.

8. Harsh Mohan's Text Book of Pathology, $5^{\text {th }}$ Ed, J.P. Brothers Medical Publication(p) Ltd. New Delhi, India. 2005. p 278-288

9. Paul durrington \& Allen $S$, Fast Facts Hyperlipidemia, IIIrd Ed.2005,health Press Oxford Publication.7-150.

10. Lopez AD, Assessing the burden of mortality from cardiovascular diseases, World health stat Q. 1993, 46:91-96.

11. Jha P, enas EA, Yusuf S. Coronary artery disease in Asian Indians prevalence and risk factors, Asian Am Pac island J health,1993,1:161-75.

12. Wilsons PWF,D' Agostino RB, levy D, Belanger AM \& other's "Prediction of Coronary heart disease using risk factor categories, Circulation”1998;97:1837-47.

13. Lipid Research Clinics Programme, the lipid research clinics, coronary primary prevention trail results I, reduction in the incidence of coronary heart disease, JAMA 1984; 251:351-74.

14. Barbara V et al, "Raising Tide of cardiovascular disease in American Indians" The Strong heart study, Circulation; 1999; 99: 2389. 
15. Parks, Text book of preventive medicine; $17^{\text {th }}$ Ed 2002; 273-78

16. Maseehi Abu-Sehal,” Kitab-ul-Maita Maseehi”, Nashrul-uloom Islamic Press, Hydrabad Dakin 1963;p 35-36,97-98, 115-158.

17. Jalinoos," Fusool-e-buqrat ma Tashkees Jalinoos”, Translated by Hkm. Gulam Husian Kantoori, Munshi Nawal Kishor Pub, Lucknow p 345-346.

18. Zakaria Razi, Al Havi fit-tib.Urdu Translation by central Council for research in Unani Medicine (CCRUM), new dehli, 1999. Vol 6, P.6:183-239

19. Rushd Ibne, ' Kitabul Kulliyat' Urdu Translation, 2. Edition, CCRUM (1986), New Delhi 1986 Pp 45-46.

20. Rushd Ibne, ' Kitabul Kulliyat' Urdu Translation, 2nd Edition, CCRUM (1986), New Delhi 1986 Pp 45-46, 294, 308.

21. Aamli M.S, Haamil-al Matn Jame-us-Sharheen, Vol.1, Matba Sultan al Matba, Lucknow 1266 Hijri, Pp 73.

22. Kabeeruddin M, Ifada-e-Kabeer Mufassal, Qaumi council Barae- Farogh Urdu Zabaan, N. Delhi 2001 Pp 24, 32, 37, 64, 65, 67, 69, 75 .
23. Arzani A.M, Akseer-ul-Qaloob, urdu translation Mufarrah-ul-Qaloob, Syed Mohd Baqir, Matba, Munshi Nawal Kishor, Lucknow 1939 Pp 31, 32, 39, 49, 50, 101, 102,105, 106, 160, 320, 321.

24. Nafees B, Kulliyat-e-Nafeesi, Part-1, Tarjuma wa Sharah, Hkm Kabeeruddin, Matba Daftarul Maseeh, Hydrabaad 1954 Pp 28, 30, 42, 43, 50, 62, 66, 67, 70, 71, $85,86$.

25. Sina Ibne, 'Alqanoon-fit-Tibb' Translated by Ghulam Husain Kintoori, Idara Kitab-us-Shifa, Kucha Chelan, Darya Ganj, New Delhi 2010 Pp 454,1445-1447.

26. Tabri R, Firdausul Hikmat (Urdu Translation), Idara Kitab-us-Shifa, Kucha Chelan, Darya Ganj, New Delhi 2010 Pp 112-113.

27. Majoosi Ali-Bin Abbas, 'Kamilul Sana'a Translated by Ghulam Husain Kintoori, Idara Kitab-us-Shifa, Kucha Chelan, Darya Ganj, New Delhi 2010 Pp104-106. 